\title{
Diffuse intravascular clotting associated with a primary brain tumour
}

\author{
Y. VARDI, M. STREIFLER, E. SCHUJMAN, AND M. LOEWENTHAL \\ From the Departments of Neurology and Pathology, Tel-Aviv Municipal-Governmental \\ Medical Center, Ichilov Hospital, the Faculty of Medicine and the Faculty of Postgraduate \\ Medical Studies, Tel-Aviv University, Tel-Aviv, Israel
}

SYNOPSIS A case of diffuse intravascular clotting associated with a primary brain tumour (oligodendroglioma) is described. The mechanisms of clotting and subsequent fibrinolytic syndromes are discussed with reference to the literature. On the basis of clinical, laboratory, and postmortem findings the possibility of the induction of diffuse intravascular clotting by primary brain tumours is stressed.

Diffuse intravascular clotting has been discussed in a number of publications from the view points of aetiological factors, pathophysiology, clinical course, and therapy (Davie and Ratnoff, 1964; Rosner and Ritz, 1966; Lasch et al., 1967; Holzknecht, 1970; Sherman, 1973).

This syndrome is a hyperactivation of the clotting and fibrinolytic systems (predominantly increased thrombin formation with a secondary plasmin reaction), and a disturbance in the platelet function-secondary thrombocytopenia and thrombocytopathia. It has been described in connection with tumours of different types, mainly malignant (Margaretten, 1967).

We report a case of fulminant diffuse intravascular clotting developing in a woman suffering from oligodendroglioma in the brain. In the literature at our disposal no report of this disorder associated with a primary brain tumour could be found.

\section{CASE REPORT}

E.E., aged 19 years, who, apart from vitiligo, had no neurological or internal medical past history of note, was admitted in stupor because of severe headaches, from which she had suffered for a few days.

The internal medical and neurological examinations were normal apart from a slight blurring of the optic disc margins. The electroencephalogram (EEG) showed a generalized disturbance, accentuated in the left hemisphere. Lumbar puncture yielded bloody xanthochromic fluid, containing $325 \mathrm{mg}$ protein, $78 \mathrm{mg}$ sugar, and $125 \mathrm{mg}$ chloride per $100 \mathrm{ml}$. The other laboratory findings were normal, except for a prothrombin level of $32 \%$. The patient lapsed into deep coma with low blood pressure, thready pulse, and respiratory irregularity leading to total arrest. Repeated electrocardiographic records showed STdepression in most leads. Consecutive EEG records became flat and remained so until her death. The patient developed severe functional kidney disturbances, acidosis, hyperkalaemia $(6.6 \mathrm{mg} / 100 \mathrm{ml}$,) hyponatraemia $(124 \mathrm{mg} / 100 \mathrm{ml})$, hyperuricaemia $(11 \mathrm{mg} / 100 \mathrm{ml})$, hypocalcaemia $(7.6 \mathrm{mg} / 100 \mathrm{ml})$, hyperphosphataemia $(15 \mathrm{mg} / 100 \mathrm{ml})$, polyuria, and finally anuria. Liver function tests were negative and so were repeated serological examinations and blood cultures. No virus could be isolated from the blood and spinal fluid.

In view of low prothrombin values and the other findings shown in Table 1 the diagnosis of diffuse

TABLE 1

SUMMARY OF LABORATORY DATA

\begin{tabular}{lrrr}
\hline \multirow{2}{*}{ Factor } & \multicolumn{3}{c}{ Day of hospitalization } \\
\cline { 2 - 4 } & \multicolumn{1}{c}{3} & \multicolumn{1}{c}{4} \\
\hline Fibrinogen $(\mathrm{mg} / 100 \mathrm{ml})$ & 204 & 210 & 150 \\
Prothrombin $(\%)$ & 32 & 20 & 24 \\
Factor V $(\%)$ & 29 & 29 & 70 \\
Factor VIII $(\%)$ & 110 & 110 & 150 \\
Thrombocytes $\left(/ \mathrm{mm}^{3}\right)$ & 230,000 & 214,000 & 128,000 \\
Bleeding time $(\mathrm{min}, \mathrm{s})$ & 3,44 & - & 9,15 \\
Prothrombin time $(\mathrm{s})$ & - & 42 & 48 \\
\hline
\end{tabular}


intravascular clotting was suspected and treatment with heparin instituted. In spite of all efforts the patient died on the fourth day of hospitalization.

PATHOLOGICAL EXAMINATION The skin showed scattered ecchymotic areas and many petechiae. These were also abundantly present in the pancreas and in the kidneys. The spleen was enlarged and contained many foci of infarction. A ruptured haemorrhagic corpus luteum cyst was found in the right ovary. The heart contained numerous subendocardial haemorrhages and yellowish foci, soft in consistency, were scattered in the left ventricular myocardium. In the brain a huge, soft mass occupied parts of the left parietal and temporal lobe and invaded the left lateral ventricle (Fig. 1). Examination of the lungs, the digestive system including liver and biliary tract, the urinary system, the thyroid, and the adrenals did not reveal any findings of note.

Histologically, the brain tumour was identified as an oligodendroglioma composed of highly uniform cells with a clear cytoplasm, perinuclear halo, and regular spheroidal nuclei (Fig. 2).

In some areas the tumour cells were around blood vessels, forming papillary structures and perivascular pseudorosettes. Here and there calcospherites were found. No neuroglial fibres, endothelial proliferation, or mitotic changes were seen. In the cerebral tissue adjacent to the tumour there were blood vessels occluded by fibrin thrombi (Fig. 3).

In the heart, scattered haemorrhagic infarcted foci were found (Fig. 4). Phosphotungstic acid haematoxylin staining gave evidence of fibrin deposits in small blood vessels in their vicinity.

In the liver, fibrin deposits and hyalin bodies were found in venules and around foci of periportal

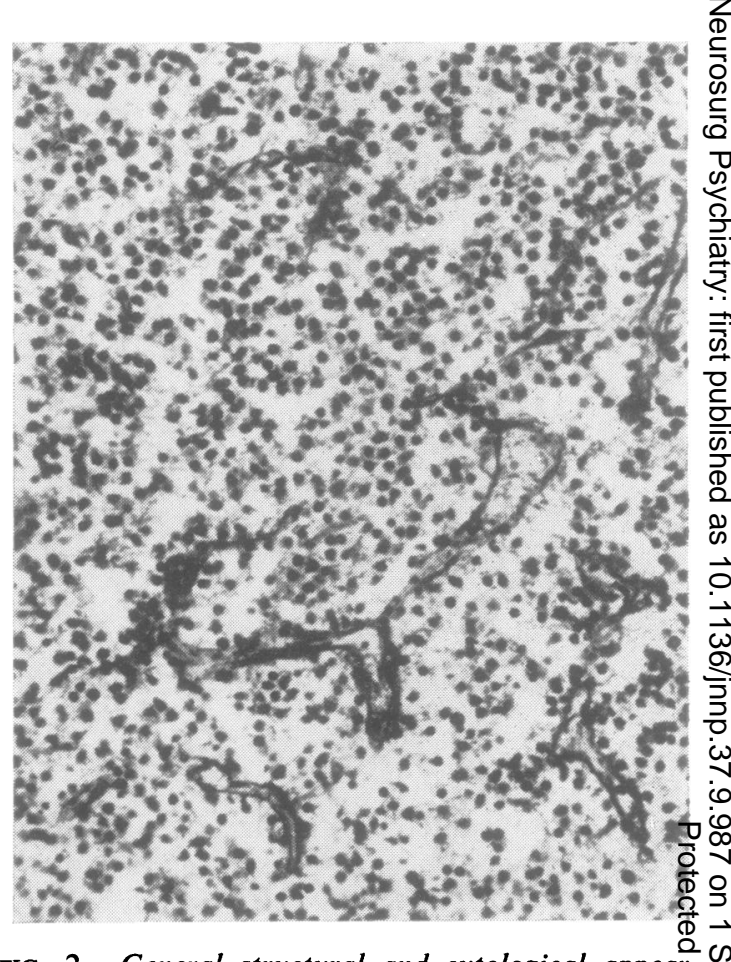

FIG. 2. General structural and cytological appeat ance of the oligodendroglioma of the left cerebral hemisphere. $H$ and $E, \times 25$.

haemorrhagic necrosis. No fibrin thrombi we found in the kidneys or in any other organ.

DISCUSSION

Phillips (1967) classified the diffuse intravascular clotting syndromes into the following four

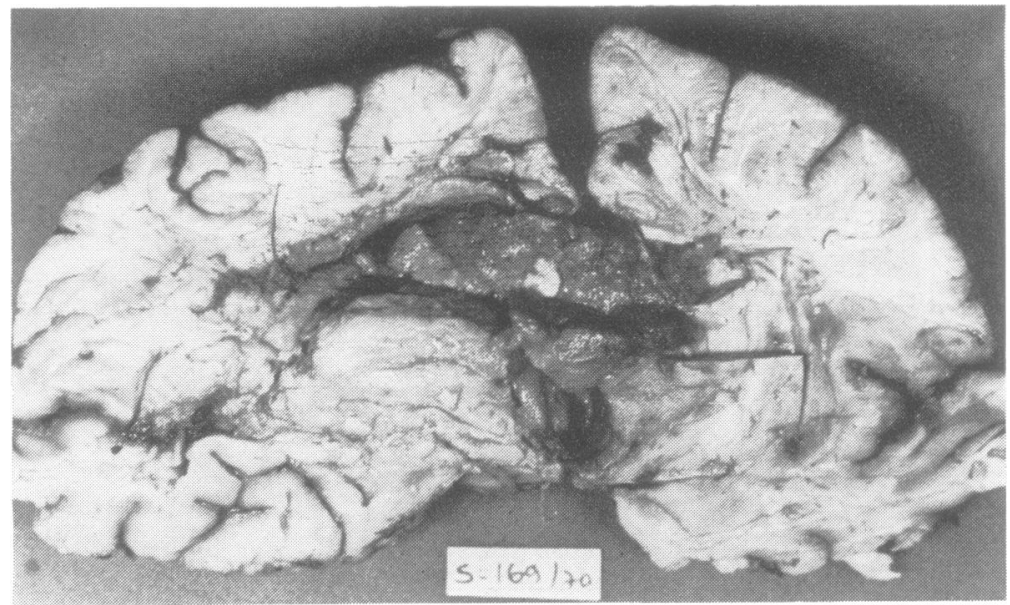

FIG. 1. Tumour of the left cerebral hemisphere invading the lateral ventricle. 


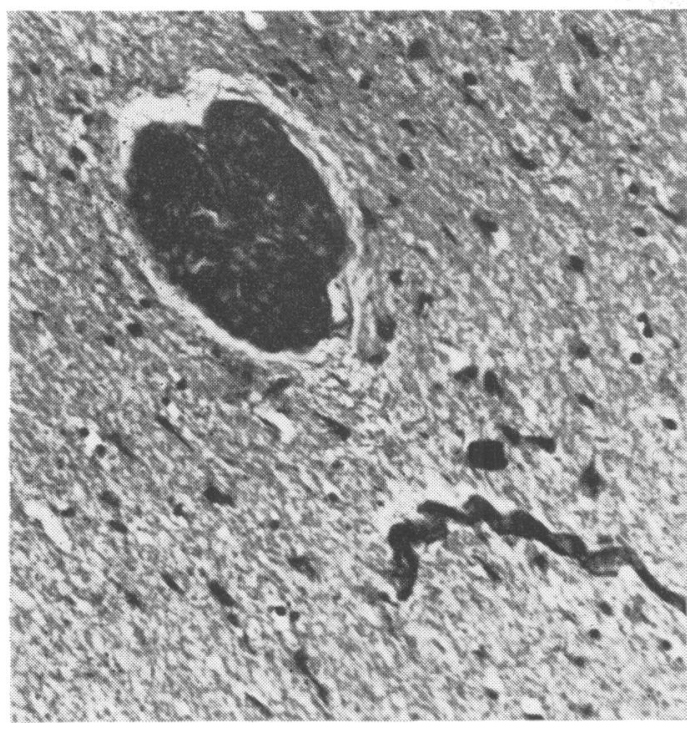

FIG. 3. A blood vessel occluded by a fibrin thrombus is seen in the vicinity of the cerebral tumour. $H$ and $E, \times 25$.

groups, according to the cardinal pathophysiological process which takes place: (1) predominantly clotting process; (2) clotting process with insufficient fibrinolytic reaction; (3) clotting process with strong fibrinolytic reaction; (4) predominantly fibrinolytic activity.

The values given in Table 2 can be found in the typical syndromes of diffuse intravascular clotting. In practice, one finds a broad array of transitional clinical states, according to the relative predominance of the disturbances in the

TABLE 2

ANALYSIS OF LABORATORY DATA

\begin{tabular}{|c|c|c|}
\hline Factor & $\begin{array}{l}\text { Intravascular } \\
\text { clotting }\end{array}$ & $\begin{array}{l}\text { Fibrinolytic } \\
\text { actions }\end{array}$ \\
\hline $\begin{array}{l}\text { Fibrinogen } \\
\qquad(\mathrm{mg} / 100 \mathrm{ml})\end{array}$ & Reduced, 25-200 & Reduced, 0-150 \\
\hline $\begin{array}{l}\text { Prothrombin } \\
(\%)\end{array}$ & $\begin{array}{l}\text { Somewhat reduced, } \\
50-90\end{array}$ & $\begin{array}{l}\text { Somewhat reduced, } \\
50-90\end{array}$ \\
\hline $\begin{array}{l}\text { Thrombocytes } \\
\left(/ / \mathrm{mm}^{3}\right)\end{array}$ & $\begin{array}{l}\text { Markedly reduced, } \\
5,000-80,000\end{array}$ & $\begin{array}{c}\text { Somewhat reduced, } \\
8,000-150,000\end{array}$ \\
\hline Factor V $(\%)$ & $\begin{array}{l}\text { Initially high, } \\
100-200 \\
\text { Later reduced, } \\
40-50\end{array}$ & $\begin{array}{l}\text { Markedly low, } \\
5-20\end{array}$ \\
\hline Factor VIII $(\%)$ & Reduced, 60-80 & $\begin{array}{l}\text { Somewhat reduced, } \\
70-90\end{array}$ \\
\hline Prothrombin time & $\begin{array}{l}\text { Initially shortened } \\
\text { and lengthened } \\
\text { later }\end{array}$ & Lengthened \\
\hline
\end{tabular}

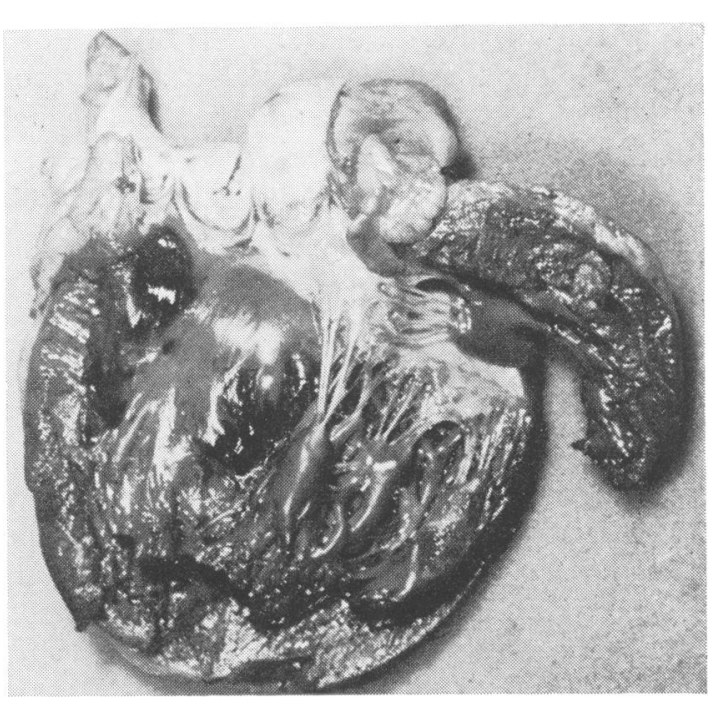

FIG. 4. In the left ventricle, several areas of subendocardial haemorrhages are seen.

clotting or the fibrinolytic system. Their dynamics and interactivities find their expressions in the changes of clotting factor values, the appearance of products of fibrin breakdown, and variations in antithrombin activity.

The laboratory data on the clotting factors in the present case do not correspond fully to any one of the syndromes described by Phillips, but they do point out the association of intravascular thrombosis with strong fibrinolysis. These laboratory values, although incomplete, are sufficient for confirming the diagnosis of diffuse intravascular clotting according to the criteria of Amir (1972) - namely, reduction of prothrombin, fibrinogen, platelets, and factors V and VIII. The lengthening of the bleeding time from $3 \mathrm{~min} 44 \mathrm{~s}$ to $9 \min 15 \mathrm{~s}$ equally supports the diagnosis. Its explanation lies not in the relative thrombocytopenia, but in the thrombocytopathic process which takes place in the course of diffuse intravascular clotting-namely, the depletion of the thrombocytes of nucleotides and of serotonin.

Congenital factor $\mathrm{V}$ deficiency is excluded in the present case by the increase of its value from $29 \%$ to $70 \%$ under heparin treatment. Because of the manifold processes which took place concomitantly (coagulation, fibrinolysis, and heparinization), there are different trends in our laboratory values, like the increase of factor VIII 
from $110 \%$ to $150 \%$, the decrease of fibrinogen from $204 \mathrm{mg} / 100 \mathrm{ml}$ to $150 \mathrm{mg} / 100 \mathrm{ml}$, the consistently low prothrombin and the slight changes in prothrombin time.

Decrease in factor $V$ values through direct hypothalamic stimulation, as demonstrated by Gunn and Hampton (1967), is excluded on pathological and haematological grounds.

The pathological findings are in accordance with the observations of Erdman (1965) and Margaretten (1967). The main pathology is the formation of fibrin precipitates is small venous and arteriolar vessels causing infarction, and secondary bleeding due to activation of a fibrinolytic process aimed at dissolving these thrombi. This explains the fact that there are blood vessels occluded with fibrin side by side with others which do not contain fibrin deposits. This is also demonstrable in the various organ sections of the present case, where one can find thrombi in some vessels, causing haemorrhagic infarcts, while other vessels are unoccluded because of the fibrinolytic process or the heparinization.

\section{REFERENCES}

Amir, J. (1972). Disseminated intravascular coagulation Harefuah, 83, 29-31.

Davie, E. W., and Ratnoff, O. D. (1964). Waterfall sequence for intrinsic blood clotting. Science, 145, 1310-1312.

Gunn, C. G., and Hampton, J. W. (1967). CNS influence on plasma levels of factor VIII activity. American Journal of Physiology, 212, 124-130.

Holzknecht, F. (1970). Disseminated intravascular coagulation. German Medical Monthly, 15, 642-645.

Lasch, H.-G., Heene, D. L., Huth, K., and Sarchitter, w (1967). Pathophysiology, clinical manifestations and therapy of consumption-coagulopathy ("Verbrauchsko음 agulopathie'). American Journal of Cardiology, 20, 381-391 कू

Margaretten, W. (1967). Local tissue damage in disseminated intravascular clotting. American Journal of Cardiology, 20 185-190.

Phillips, L. L. (1967). Alterations in the blood clotting system $\vec{b}$ in disseminated intravascular coagulation. American Journal of Cardiology, 20, 174-184.

Rodríguez-Erdmann, F. (1965). Hemorrhagic syndromeso caused by consumption of blood-clotting factors (con sumption-coagulopathies). New England Journal of Medicine, 273, 1370-1378.

Rosner, F., and Ritz, N. D. (1966). The defibrination syn: drome. Archives of Internal Medicine, 117, 17-24.

Sherman, L. A. (1973). Therapeutic problems of disseminativ intravascular coagulation. Archives of Internal Medic $\overline{\mathbb{Q}}$, 132, 446-453. 